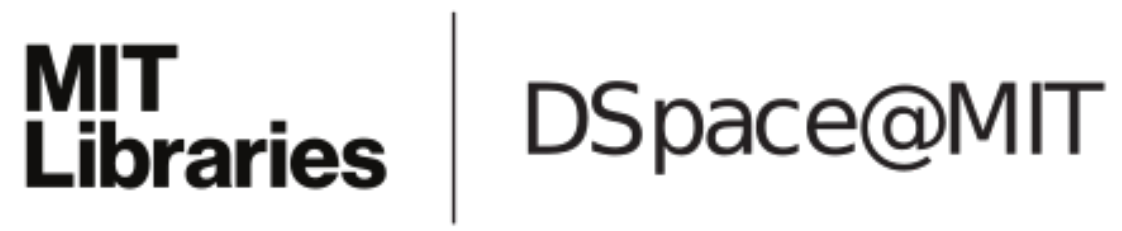

\author{
MIT Open Access Articles
}

\section{Reducing Evaporative Water Losses from Irrigation Ponds through the Reuse of Polyethylene Terephthalate Bottles}

The MIT Faculty has made this article openly available. Please share how this access benefits you. Your story matters.

Citation: Simon, K., R. Shanbhag, and A. H. Slocum. "Reducing Evaporative Water Losses from Irrigation Ponds through the Reuse of Polyethylene Terephthalate Bottles." J. Irrig. Drain Eng. (October 9, 2015): 06015005.

As Published: http://dx.doi.org/10.1061/(ASCE)IR.1943-4774.0000972

Publisher: American Society of Civil Engineers (ASCE)

Persistent URL: http://hdl.handle.net/1721.1/99893

Version: Author's final manuscript: final author's manuscript post peer review, without publisher's formatting or copy editing

Terms of use: Creative Commons Attribution-Noncommercial-Share Alike 


\title{
Reducing Evaporative Water Losses from Irrigation Ponds Through the Re-Use of Polyethylene Terephthalate Bottles
}

\author{
K. Simon ${ }^{1}$, R. Shanbhag ${ }^{2}$, A. H. Slocum ${ }^{3}$
}

\begin{abstract}
Evaporation is one of the sources of water loss from artificial reservoirs used in agriculture sector. Current methods of covering artificial reservoirs are too costly to use by poor, small-scale farmers. This paper presents a method for using waste polyethylene terephthalate (PET) bottles to reduce the evaporative losses from open tanks. This water-conservation method was tested using eight evaporation pans with daily waterlevel measurements to record evaporation rate. Four pans were used as controls, two were covered with empty waste PET bottles, and two were covered with bottles partially filled with soil. The experiment showed an average reduction in evaporation by $40 \%$ with the PET bottle treatment, with a $90 \%$ confidence of reducing evaporation by at least $18 \%$. The addition of soil did not affect the degree of evaporation reduction. Given the local economics of the region surrounding Pune, India, it was found that this intervention can save water at a cost of $0.09 \mathrm{US} \$ / \mathrm{m}^{3}$.
\end{abstract}

Author keywords: PET bottle, Irrigation tank, Water conservation, Evaporation reduction, Waste management, Floating covers, Evaporation pan, Bootstrap

\section{INTRODUCTION}

Agriculture is the main source of water use, representing $70 \%$ of global water consumption. In 2013, 25\% of the world's irrigated agricultural systems were withdrawing water faster than the regional replenishment rate (Rengel 2013). This challenge of sustainably managing water is acutely noticed in developing countries. In 2010, India consumed $761 \times 10^{9} \mathrm{~m}^{3}$ of water, out of which $90 \%$ was used by agriculture sector (FAO 2011).

Evaporation accounts for a little over $2 \%\left(16.95 \times 10^{9} \mathrm{~m}^{3} /\right.$ year in 2011) of India's effective water consumption (Frenken 2011). This paper proposes the use

\footnotetext{
${ }^{1}$ Engineering Systems Division, MIT, 77 Massachusetts Ave., Cambridge, MA 02139. Email: KevinPsi@mit.edu

${ }^{2}$ Vigyan Ashram, Pabal, Dist. Pune, Maharashtra, India 412403

${ }^{3}$ Mechanical Engineering, MIT, 77 Massachusetts Ave., Cambridge, MA 02139
} 
of waste PET bottles as floating covers to reduce water-scarcity as a less expensive and potentially scalable solution to reduce evaporation from man-made irrigation storage systems by approximately $40 \%$.

Discussions with farmers near Pabal, India identified concerns about the rate of evaporation loss from their water retaining ponds, often referred to as irrigation tanks' in India. Suspended and floating covers have been used to reduce evaporation in industrial applications and with large reservoirs (Yao 2010). These existing solutions cost from 8 to $30 \mathrm{US} \$ / \mathrm{m}^{2}$ of reservoir, which are not only expensive but also unable to handle high-winds and unable to capture rain. This paper proposes and tests a method for using PET bottles as floating covers that are less expensive than existing evaporation reduction methods. In preliminary tests, it was found that those bottle rotate, exposing water film to air and increasing evaporation. To address this challenge, and to prevent the bottles from being blown away in stronger winds, a small amount of soil was added to each bottle in half of the treatments. When rain falls on the floating bottles, it passes between them.

There are popular concerns about chemicals leaching from PET bottles into water when exposed to sunlight and heat. However, review of literature on chemical leaching has revealed that the leaching of dangerous chemicals into irrigation ponds is well below the dangerous limits (Gorbaty 2013). Only one reviewed experiment exceeded human health limits for any contaminant, antimony in this case, for a $0.5 \mathrm{~L}$ bottle. That experiment was conducted at $80^{\circ} \mathrm{C}$ to simulate the inside of a sealed truck in Arizona, USA. The PET bottles will never reach the $80^{\circ} \mathrm{C}$ point when used as floating covers because they will be in open air conditions. Furthermore, irrigation ponds are much larger than the volume of plastic bottles, further reducing the risk of toxic chemicals leaching in dangerous concentrations.

There are similar concerns surrounding the disposal of these bottles at the end of their use as a floating cover. PET can withstand photo, thermal, and biological degradation for 20-50 years, so it is likely that the bottles will still be intact when they are replaced or finished (Webb 2012). Fortunately, PET bottles have value as recyclable materials. Because the PET bottles have already been aggregated at the storage tank, they can be sold to waste-pickers or waste-aggregators at a small price.

\section{MATERIALS AND METHODS}

The experiment consisted of daily measurements taken from eight evaporation pans, which can be seen in Figure 1, from March 5th to May 24th 2014. This time-window was chosen because it is the hottest and driest in Maharashtra. Only data from March 5th to April 20th were used because of leakage. Out of eight pans, four were uncovered and designated as control, two were covered with empty PET bottles, and the last two were covered with $500 \mathrm{ml}$ PET bottles containing $10 \mathrm{~g}$ of soil. Each pan was made from a rolled piece of metal, welded into a $400 \mathrm{~mm}$ tall, 1.5 meter diameter cylinder and lined with white tarpaulin to 
prevent leakage into the soil. Those pans were filled with approximately $270 \mathrm{~mm}$ of water and refilled when empty. A wire mesh was placed over the evaporation pans to prevent the bottles from blowing away in high wind, and to prevent animals drinking from the pans. The Vigyan Ashram, based near the village of Pabal, outside of Pune, collected data for the experiment. Every day at 5:00 pm IST, depth measurements were taken with a scale mounted to a stand.

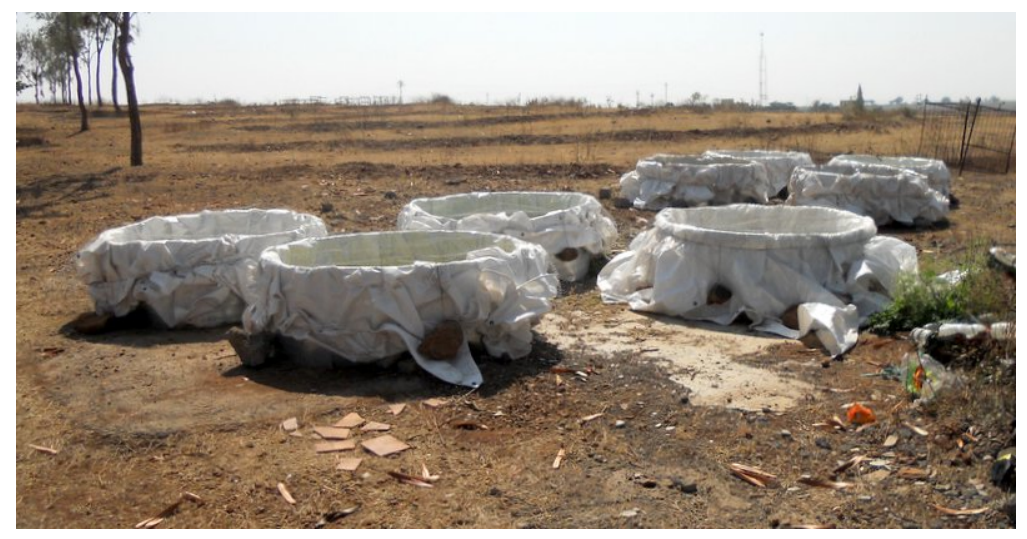

FIG. 1: The evaporation ponds from the experimental setup.

The mean shift of the evaporation rate was calculated for each day. This calculation prevented variations in the weather from influencing the results. The remaining sources of error could be caused by albedo or leakage. Using the same tarpaulin in each pond ensured that their albedo is similar. Leakage was the only major source of error unaccounted for in the experimental design. A sudden drop in water level indicated a leak, which would be excluded from the final analysis.

\section{RESULTS}

The cumulative evaporation rate can be seen in Figure 2. Table 1 shows that the data had low skew and high kurtosis. Using the absolute water level to calculate the evaporation rate made the measurement error symmetric. Measurement error from reading the scale by eye was the source of the high kurtosis. These measurement errors were identified by examining the net evaporation rate, and were likely the cause of the long tails. Because of the data's high kurtosis it was not normal. The long tails, indicating non-normality, are also seen in Figure 3. A Bootstrap resampling was used to determine the confidence intervals (Efron 1979). This measurement error can be reduced by using a more accurate measurement instrument, such as a sight glass. 
TABLE 1: Skew and kurtosis of the datasets

\begin{tabular}{c|cc} 
Variable & Skew & Kurtosis \\
\hline Control & 0.59 & 11.57 \\
Empty Bottles & 3.63 & 31.76 \\
Soil-filled Bottles & 0.64 & 12.40 \\
\hline
\end{tabular}

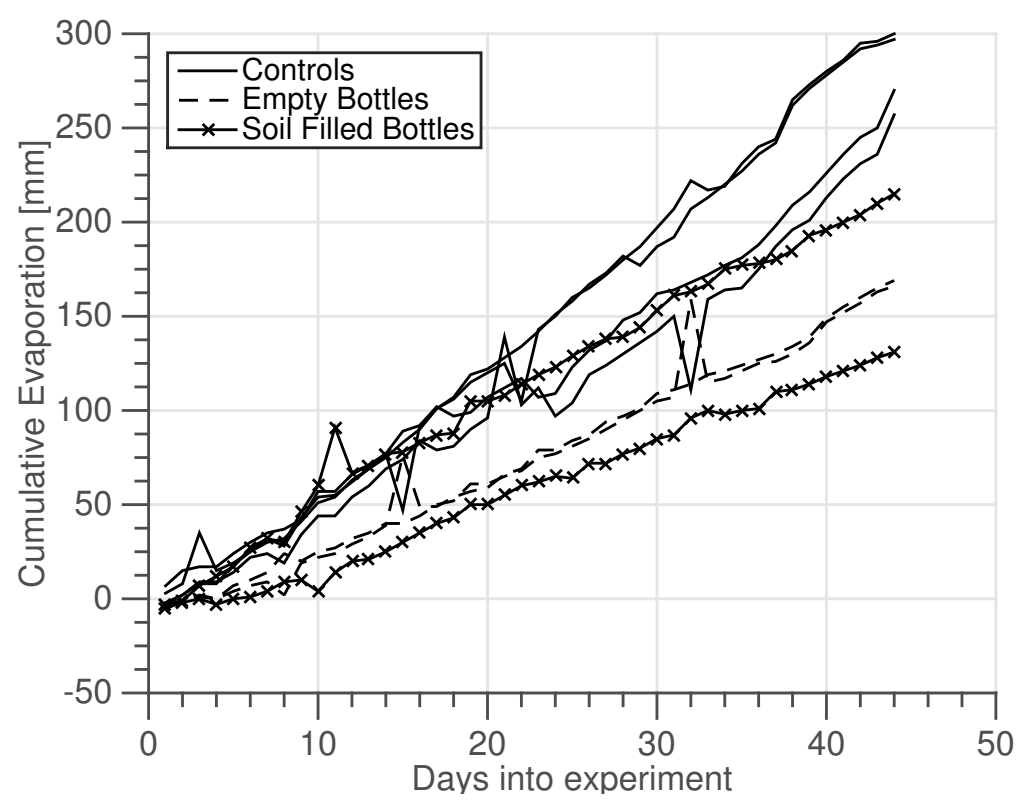

FIG. 2: The total water evaporation from each pan in the experiment. 

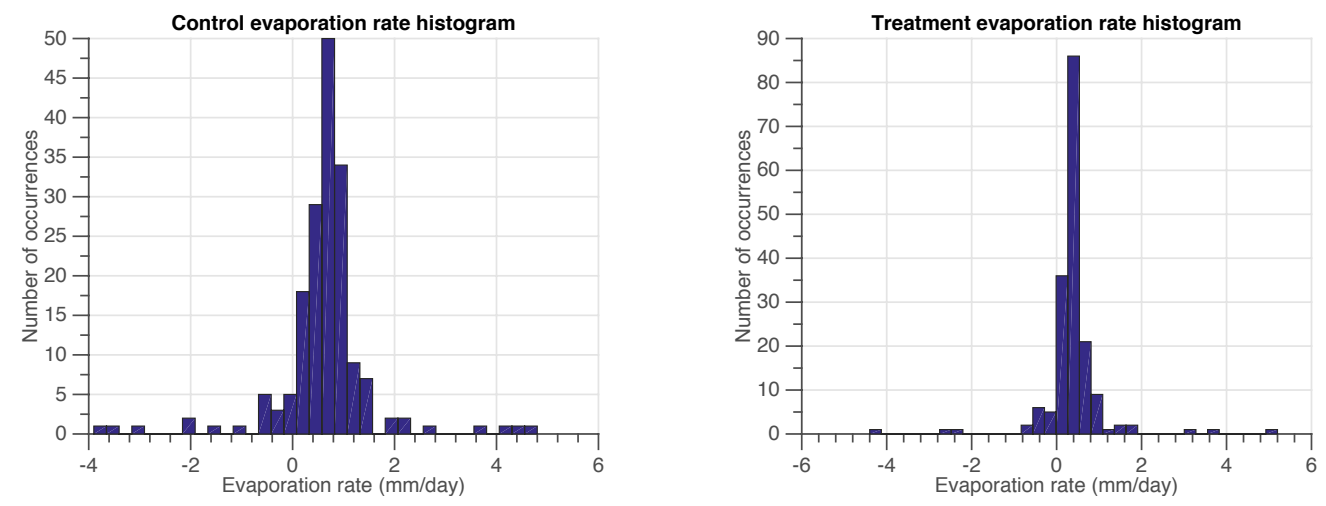

FIG. 3: The histograms of the evaporation rates for the treatments and controls.

The ANOVA-multicompare in Figure 4, performed in MATLAB (2014b), from the pre-leak data showed an insignificant difference between the two treatments, and a significant difference $(\mathrm{p}=0.1)$ between the bottle treatments and the control. 


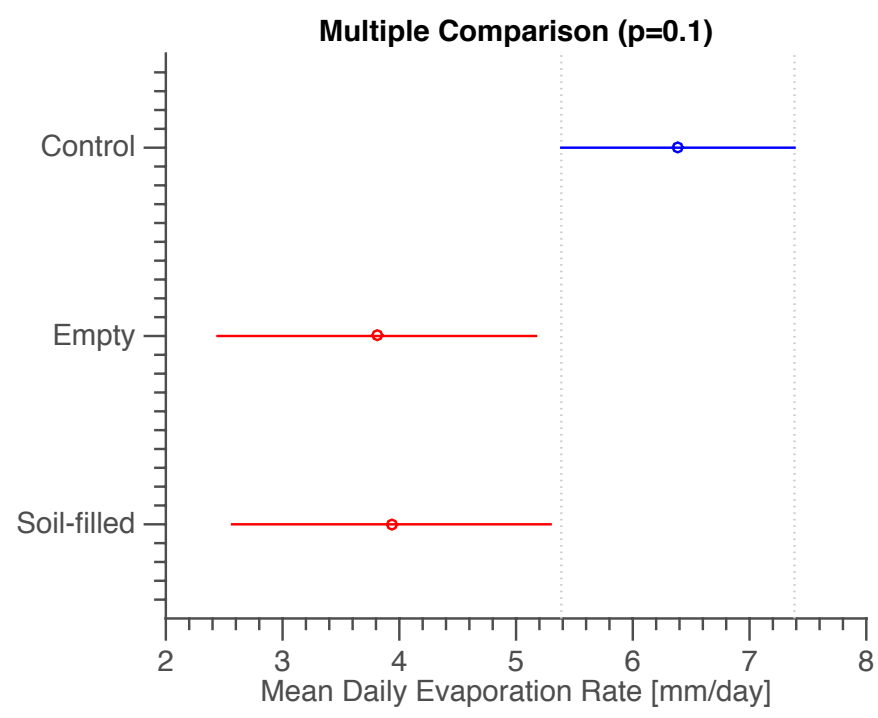

FIG. 4: The graphical results of a multi compare test with a p-value of 0.1 .

The collected data has a mean-shift from $6.0 \mathrm{~mm} /$ day with the control to $3.8 \mathrm{~mm} /$ day with the soil-bottle treatment. This is a $2.2 \mathrm{~mm} /$ day reduction in evaporation, amounting to a $37 \%$ mean shift $\left(\%\right.$ reduced $\left.=\frac{\Delta x}{x_{\text {control }}}\right)$. It was found, within a $90 \%$ confidence interval, that the average evaporation rate was reduced by at least $1.1 \mathrm{~mm} /$ day $(18 \%)$. The control evaporation rate of 6.0 $\mathrm{mm}$ /day closely matches the data presented by the Indian government (Sinha 2006). Therefore, this analysis will be based on the Indian government's data for yearly evaporation rates in Pabal: $2250 \mathrm{~mm} /$ year. It is assumed that the fractional reduction in evaporation remains constant.

\section{ANALYSIS}

The value of this evaporation reduction method is dependent on the economics of PET waste and the price or value of water. This section considers the costs and benefits associated with using waste PET bottles as floating covers by examining the price of irrigation water and the price of PET bottles. In this paper, the 
value of the intervention is calculated as the difference between the cost of water saved, and the cost of covering a pond with PET bottles.

\section{Price of Water}

There are many ways to determine the value of water (market price, cost of production, social value). The most simple metric is the price paid for irrigation water by farmers. This metric does not capture the value of water in water scarce regions, where increased water could improve or save the yield of a crop, but it does provide a baseline.

There is a large variability in the pricing of water schemes (Cornish 2004; Saleth 1997). The cost of pumped groundwater is used as the benchmark for the price of water. A farmer in Pabal, Maharashtra who consumes $100 \mathrm{~m}^{3}$ of water per day on average consumes approximately $300 \mathrm{US} \$$ /year in electricity. A pump capable of providing that amount of water would likely cost about 150 US\$ and needs to be replaced every 4 years on average. This farmer would consume about $10,000 \mathrm{~m}^{3}$ of water over the course of 100 days of irrigation each year. The cost of irrigation water in Pabal was estimated to be $0.035 \mathrm{US} \$ / \mathrm{m}^{3}$ of water. This value is close to the energy cost of lifting $1 \mathrm{~m}^{3} 30 \mathrm{~m}$ with a $20 \%$ efficient pump and an electricity cost of $0.08 \mathrm{US} \$ / \mathrm{kWh}$, about $0.032 \mathrm{US} \$ / \mathrm{m}^{3}$. It should be noted that other farmers in the region received subsidized irrigation, paying $1 / 10^{\text {th }}$ the market electricity rate.

Other regions in Maharashtra, Aurangabad in this case, reported groundwater irrigation costs as great as $0.50 \mathrm{US} \$ / \mathrm{m}^{3}$ (Foster 2008). Furthermore, irrigation wells run dry for many farmers in Pabal after April. Some farmers overcome this challenge by importing water from nearby reservoirs to irrigate high-value crops such as mango-trees. The cost of importing water via truck for one farmer was noted to be about $1.16 \mathrm{US} \$ / \mathrm{m}^{3}$ that sets an upper bound for acceptable water costs.

The proposed solution will have even more value in parts of the world where water is more expensive and evaporation rates are very high as compared to Pune which is $2250 \mathrm{~mm}$ /year. In places like Australia, which also use open water storage tanks, annual evaporation can be as great as 3,000 mm/year (Craig 2005), further increasing the value of this intervention. The application of this solution to other water scarce regions in the world should be investigated further.

\section{Price of PET Bottles}

The net value of using PET bottles for irrigation includes the value of those PET bottles, either as the opportunity cost or the price to purchase. This determined the cost-benefit of using these bottles for evaporation reduction. The price of recycled PET bottles in India was reported to vary from $0.03 \mathrm{US} \$ / \mathrm{kg}$ to 0.02 US\$/bottle (Dasgupta 2008). It was found that wholesalers in Pune typically purchased PET scrap for between 0.50 and $0.67 \mathrm{US} \$ / \mathrm{kg}$ (Gorbaty 2013). The value $0.58 \mathrm{US} \$ / \mathrm{kg}$ was used in this study. The PET bottle used in this study weighed $20 \mathrm{~g}$. The common PET bottle, seen in Figure 5, had a height of $267 \mathrm{~mm}$ and a width of $76 \mathrm{~mm}$. This gave a cross-section of approximately $0.02 \mathrm{~m}^{2}$. Under 
TABLE 2: Summary of the estimated price of water conserved by using PET bottles as floating covers.

\begin{tabular}{l|ccc} 
Value & Optimistic & Estimate & Pessimistic \\
\hline \hline Price of Water [US $\$ / \mathrm{m}^{3}$ ] & 1.16 & 0.50 & 0.035 \\
\hline Price of PET Waste [US $\$ / \mathrm{kg}]$ & 0.03 & 0.58 & 0.75 \\
Bottle Weight $[\mathrm{g}]$ & 20 & 20 & 28 \\
Cross-section $\left[\mathrm{m}^{2}\right.$ ] & 0.028 & 0.02 & 0.012 \\
Avg. Yearly Evaporation [mm/year] & 2250 & 2250 & 2250 \\
Evaporation Reduction [\%] & 58 & 40 & 18 \\
Bottle lifetime [years] & 20 & 10 & 1 \\
\hline Bottle Price [US $\$$ ] & 0.001 & 0.012 & 0.015 \\
Filled Bottle Price [US $\$$ ] & 0.006 & 0.017 & 0.020 \\
Filled Coverage Price [US $\$ / \mathrm{m}^{2}$ ] & 0.28 & 0.85 & 0.98 \\
\hline Cost of Saved Water $\left[\mathrm{US} \$ / \mathrm{m}^{3}\right.$ ] & 0.01 & 0.09 & 2.42 \\
\hline
\end{tabular}

these assumptions, the cost of covering an irrigation tank was approximately 0.85 $\mathrm{US} \$ / \mathrm{m}^{2}$.

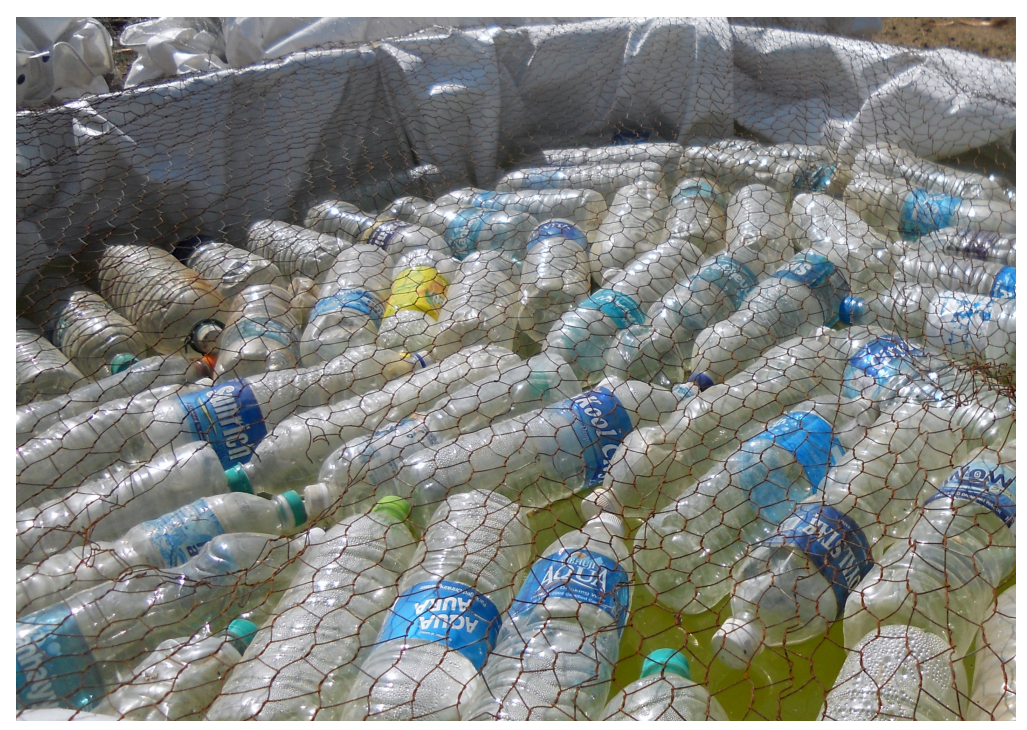

FIG. 5: An evaporation pond from the experiment with the empty bottle treatment.

The recorded mean-reduction in evaporation demonstrated in this paper is approximately $40 \%$. The average annual evaporation rate presented above comes from a report published by the Government of India's Central Water Commission (Sinha 2006). If it takes 1 minute to add soil to a bottle, and a typical unskilled 
laborer is paid $0.30 \mathrm{US} \$ /$ hour, it will cost an additional $0.005 \mathrm{US} \$ /$ bottle. The cost of transporting bottles can vary significantly, and is left out of this calculation. Note that many regions that use water tanks as storage will be in places with low population density and low income. The regional cost of transporting whole PET bottles will need to be considered. One estimate of shipping costs is provided below.

A summary of the cost estimates analysis with additional upper and lower bounds is given in Table 2. The estimated cost to conserve water with PET bottle floating covers, assuming that the bottles will last for five years, is 0.09 $\mathrm{US} \$ / \mathrm{m}^{3}$ of water. This is greater than the estimated cost of pumping water in Pabal; $1 / 5^{\text {th }}$ the cost of pumping water in Aurangabad; and $1 / 11^{\text {th }}$ cost of importing water. Compared to other interventions, such as tarps, this can save water at $1 / 3^{r d}$ the cost or less (Sinha 2006). There are many places in the world where water cannot be found in ground-wells during the dry season. In those places the PET bottles could enable increased crop yield in addition to reduced irrigation costs.

\section{PET bottle availability}

The availability of PET bottles affects how broad of an impact that this innovation could have. It is estimated that Pune produces about 1,168 tons of PET bottles/year (Gorbaty 2013). The most common irrigation tank size in Maharashtra has a surface area of $900 \mathrm{~m}^{2}$. This means that it would require approximately 45,000 bottles, or $900 \mathrm{~kg}$, to cover one typical tank. If all PET bottle waste produced by Pune were used as floating covers, is would cover approximately 1,300 tanks each year. There are a total of 208,000 irrigation tanks in India (Vaidyanathan 2001). If the bottles last for 10 years, 16 cities of equivalent size to Pune would be required to cover all of the irrigation tanks in India.

Shipping the 2000 bottles hwas estimated to cost $0.66 \mathrm{US} \$ / \mathrm{km}$ (Gorbaty 2013). At $0.00033 \mathrm{US} \$ /$ bottle $/ \mathrm{km}$, the transportation costs for bottles with 0.02 $\mathrm{m}^{2}$ cross-sectional area are $0.0165 \mathrm{US} \$ / \mathrm{m}^{2} / \mathrm{km}$. At this rate, shipping the bottles $50 \mathrm{~km}$ to an irrigation tank doubles the cost of the intervention, putting it at 0.18 $\mathrm{US} \$ / \mathrm{m}^{3}$. Adapting the solution to keep the bottle sources as local as possible will be important for preserving the economic value of this intervention.

\section{CONCLUSION}

This paper identifies a method for putting a common waste to use for reducing water evaporation by at least $18 \%(\mathrm{p}=0.1)$ with a mean reduction of $40 \%$. Compared to other evaporation reduction methods, such as tarps, this intervention can be delivered at $1 / 3^{r d}$ the cost. The effect of using PET bottles as floating covers has been demonstrated in the village of Pabal, India. It has been shown that the cost of this intervention can be greater or less than the value of the saved water depending on the local context.

\section{FUTURE WORK}

Due to the cost of PET bottles, this solution will be effective only in regions where water is scarce and waste PET bottles are also available. In poor areas 
with low-population density, the bottles will need to be shipped to the irrigation tanks, adding a cost to the solution that will need to be taken into account.

This paper also discusses the nature of data collected remotely with high measurement induced kurtosis. The measurement method described in this paper produces statistically useful data with a simple, and low-cost setup when combined with a bootstrap analysis. This setup can be scaled to engage farmers in different regions of India to test and compare this and other evaporation reduction methods.

Filling the bottles with soil is necessary for preventing bottle rotation and accounts for about $1 / 3^{\text {rd }}$ of the total cost of the intervention. Square bottles, which have more resistance to rotation, could be used without soil if the dynamics of bottle rotation, which brings a film of water to the surface which then evaporates, are better understood.

Many farmers currently do not use all of the water in their pond because evaporation causes a dramatic increase in salt or other chemicals. Future work

will study the effects of reducing the concentration of these undesired chemicals in the water.

\section{ACKNOWLEDGEMENTS}

We would like to thank Vishal Jagtap, Dr. Yogesh Kulkarny, and the rest of the Energy \& Environment section of the Vigyan Ashram, India for conducting the evaporation pan experiment, evaluating water quality, helping our understanding of small scale farming around Pune, and their excellent hospitality. We would also like to thank the Tata Center at MIT. Without their support for travel and research, this would not have been possible. 


\section{REFERENCES}

Cornish, G. and Bosworth, B. (2004) "Annex 1." Water charging for irrigation, <http://www.fao.org/docrep/008/y5690e/y5690e0b.htm> (Oct 20, 2014).

Craig, I., Green, A., Scobie, M., and Schmidt, E. (2005) "Controlling evaporation loss from water storages." National Centre for Engineering in Agriculture Australia publication No. 1000580/1, National Centre for Engineering in Agriculture, University of Southern Queensland Toowoomba, Tootoomba QLD, Australia.

Dasgupta, B. and Khurana, S. (2008) "Waste management of PET bottles." Journal of Environmental Research And Development, 2, 862-867.

Efron, B. (1979) "Bootstrap methods: another look at the jacknife." The Annals of Statistics, 7(1), 1-26.

Food and Agriculture Organization of the United Nations (FAO) (2011) "India," Aquastat, <http://www.fao.org/nr/water/aquastat/countries_regions/ IND/index.stm> (Oct. 20, 2014).

Foster, S. (2008) "Ground water use in aurangabad - a survey and analysis of social significance and policy implications for a medium-sized Indian city" Sustainable Groundwater Management: Lessons from Practice, No. 21. Washington D.C., USA.

Frenken, K. (2011) "Irrigation in Southern and Eastern Asia in figures." FAO Water Reports No. 37, Food and Agriculture Organization of the United Nations, Rome, Italy.

Gorbaty, E. (2013) "Development of an efficient off-grid pumping system and evaporation reduction strategies to increase access to irrigation for smallholder farmers in India." report presented to Massachusetts Institute of Technology, at Cambridge, MA, in partial fulfillment of the requirements for the degree of Master of Engineering.

version 8.4.0, (2014b), (computer software), The MathWorks Inc., Natick, Massachusetts.

Rengel, Z. (2013) "Current state and future potential of global food production and consumption." Improving water and nutrient-use efficiency in food production systems. Oxford: Wiley-Blackwell, 10.

Saleth, R. (1997) "Water pricing experiences: an international perspective." World Bank Technical Paper No. 386, Washington, D.C., USA.

Sinha, S. (2006) "Evaporation control in reservoirs." Government of India, Central Water Commission, Basin Planning and Management Organization, New Delhi, India.

Vaidyanathan, A. (2001) Tanks of South India. New Delhi: Centre for Science and Environment, New Delhi, India.

Webb, H., Arnott, J., Crawford, R., and Ivanova P. (2013) "Plastic degradation and Its environmental implications with special reference to poly(ethylene terephthalate)." Polymers, 5, 1-18.

Yao, X., Zhang, H., Lemckert, C., Brook, A., and Schouten, P. (2010) "Evaporation Reduction by Suspended and Floating Covers: Overview, Modeling, and 
Efficiency." Urban Water Security Research Alliance Technical Report No. 28, Griffith University, Queensland, Australia. 